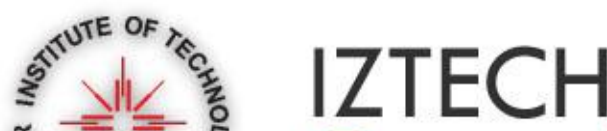 \\ Open Access Articles
}

\section{Synthesis and Photophysical Characterizations of Thermal -Stable Naphthalene Benzimidazoles}

The IZTECH Faculty has made this article openly available. Please share how this access benefits you. Your story matters.

\begin{tabular}{l|l|}
\hline Citation & $\begin{array}{l}\text { Erten, Ş, Özçelik, S, and Eren, E, "Synthesis and } \\
\text { Photophysical Characterizations of Thermal -Stable } \\
\text { Naphthalene Benzimidazoles" Journal of Fluorescence } ~ \\
\text { 2011 Springer }\end{array}$ \\
\hline As Published & http:// 10.1007/s10895-011-0845-z \\
\hline Publisher & Springer Science+Business Media \\
\hline Version & PUBLISHED ARTICLE \\
\hline Accessed & FRI JULY 5 11:44:23 GMT 2013 \\
\hline Citable Link & http://hdl.handle.net/11147/ \\
\hline Terms of Use & $\begin{array}{l}\text { Article is made available in accordance with the publisher's } \\
\text { policy and may be subject to Turkish copyright law. Please } \\
\text { refer to the publisher's site for terms of use. }\end{array}$ \\
\hline & \\
\hline Detailed Terms & \\
\hline
\end{tabular}




\title{
Synthesis and Photophysical Characterizations of Thermal -Stable Naphthalene Benzimidazoles
}

\author{
Sule Erten-Ela $\cdot$ Serdar Ozcelik $\cdot$ Esin Eren
}

Received: 24 November 2010 / Accepted: 10 January 2011 /Published online: 29 January 2011

(C) Springer Science+Business Media, LLC 2011

\begin{abstract}
Microwave-assisted synthesis, photophysical and electrochemical properties of thermal-stable naphthalene benzimidazoles and naphthalimides are studied in this paper. Microwave-assisted synthesis of naphthalene benzimidazoles provide higher yields than the conventional thermal synthesis. Comparative photophysical properties of naphthalene benzimidazoles and naphthalimides are revealed that conjugation of electron-donating group onto naphthalimide moiety increases fluorescence quantum yields. Fluorophore-solvent interactions are also investigated using Lippert-Mataga equation for naphthalimides and naphthalene benzimidazoles. Thermal stabilities of naphthalene benzimidazoles are better than naphthalimides due to increased aromaticity. The experimental $\mathrm{E}_{\mathrm{LUMO}}$ levels of naphthalene benzimidazoles are found to be between 3.15 and $3.28 \mathrm{eV}$. Therefore, naphthalene benzimidazole derivatives consisting of anchoring groups are promising materials in organic dye sensitized solar cells.
\end{abstract}

Keywords Naphthalene benzimidazole $\cdot$ Naphthalimide Absorption - Emission $\cdot$ Cyclic voltammetry $\cdot$ TGA curves

\footnotetext{
S. Erten-Ela $(\bowtie) \cdot$ E. Eren

Ege University, Solar Energy Institute,

35100 Bornova, Izmir, Turkey

e-mail: suleerten@yahoo.com

S. Erten-Ela

e-mail: sule.erten@ege.edu.tr

S. Ozcelik

Chemistry Department, Izmir Institute of Technology,

Urla, 35430 Izmir, Turkey
}

\section{Introduction}

Naphthalimides are well-known as promising anticancer agents showing broad-spectrum activity against a variety of human solid tumor cells $[1,2]$. Several derivatives have reached the phases of clinical trials [3]. N-Substituted 1,8naphthalimides find a wide range of applications as organic dyes and luminophores.

1,8-Naphthalimides are generally fluorescent compounds for which a series of biological (local anesthetics [4], DNA cleaving agents [5], tumoricidals [6] and non-biological optical brighteners [7], lucifer dyes [8]) applications have been found. 1,8-Naphthalimide and bisnaphthalimide derivatives are promising anticancer agents $[9,10]$, the sulfonated derivatives are good antiviral agents with selective in vitro activity against the human immunity deficiency virus, HIV-1 [11]. Due to their photo-physical and photo-chemical properties the 1,8-naphthalimide derivatives can be used as fluorescence dyes for solar energy collectors and photosynthesis under concentrated sunlight [12], fluorescent markers in biological cells [13] as well as laser active media [1416]. Recently, naphthalimides have also found applications in organic thin film field-effect transistors (OFETs), integrated circuit, displays, memory cards, chemical and pressure sensors, smart price tags and labels [17].

The electronic absorption and emission spectra of naphthalimides are effected by substitutions. In general, naphthalimides present lower fluorescence quantum yields. Photophysical behaviors of naphthalene benzimidazoles are different from naphthalimides. Conjugation of electrondonating groups onto naphthalimide moiety increases fluorescence emission. This study presents the microwave assisted synthesis of thermal-stable naphthalene benzimidazoles. Fluorescence quantum yields of NB_I and NB_II are found to be 0.36 and 0.60 , respectively. This is very 
Table 1 Synthesized naphthalimide and naphthalene benzimidazole derivatives

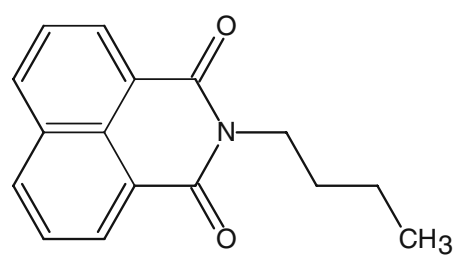

NI_I

N-Butyl-1,8-naphthalimide

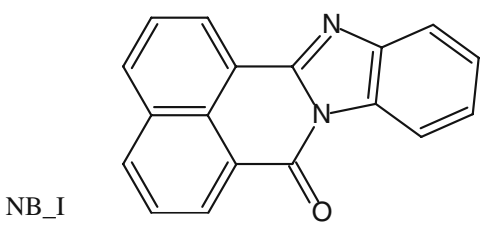

1,8-Naphthalene benzimidazole

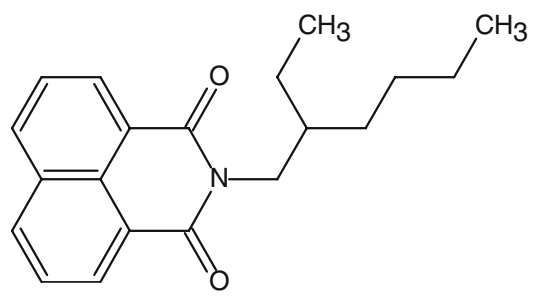

NI_II

N-2-Ethyl hexyl-1,8-naphthalimide

NB_II<smiles>O=c1c2cccc3cccc(c32)c2nc3ccncc3n12</smiles>

1,8-Naphthalene(3,4-pyridine imidazole)

method has some advantages such as high reaction yield, faster reaction time, rapid heating of the medium, enhanced reaction selectivity and saving energy due to completed reactions in short time.

And also, general and specific solvent effects of naphthalene benzimidazoles (NBs) and naphthalimides (NIs) were investigated using Lippert-Mataga equation. Molecular structures of naphthalimide (NI) and naphthalene benzimidazole (NB) derivatives are presented in Table 1.

Fig. 1 Cyclic voltammogram of NI_II (a), and NB_I (b), in acetonitrile

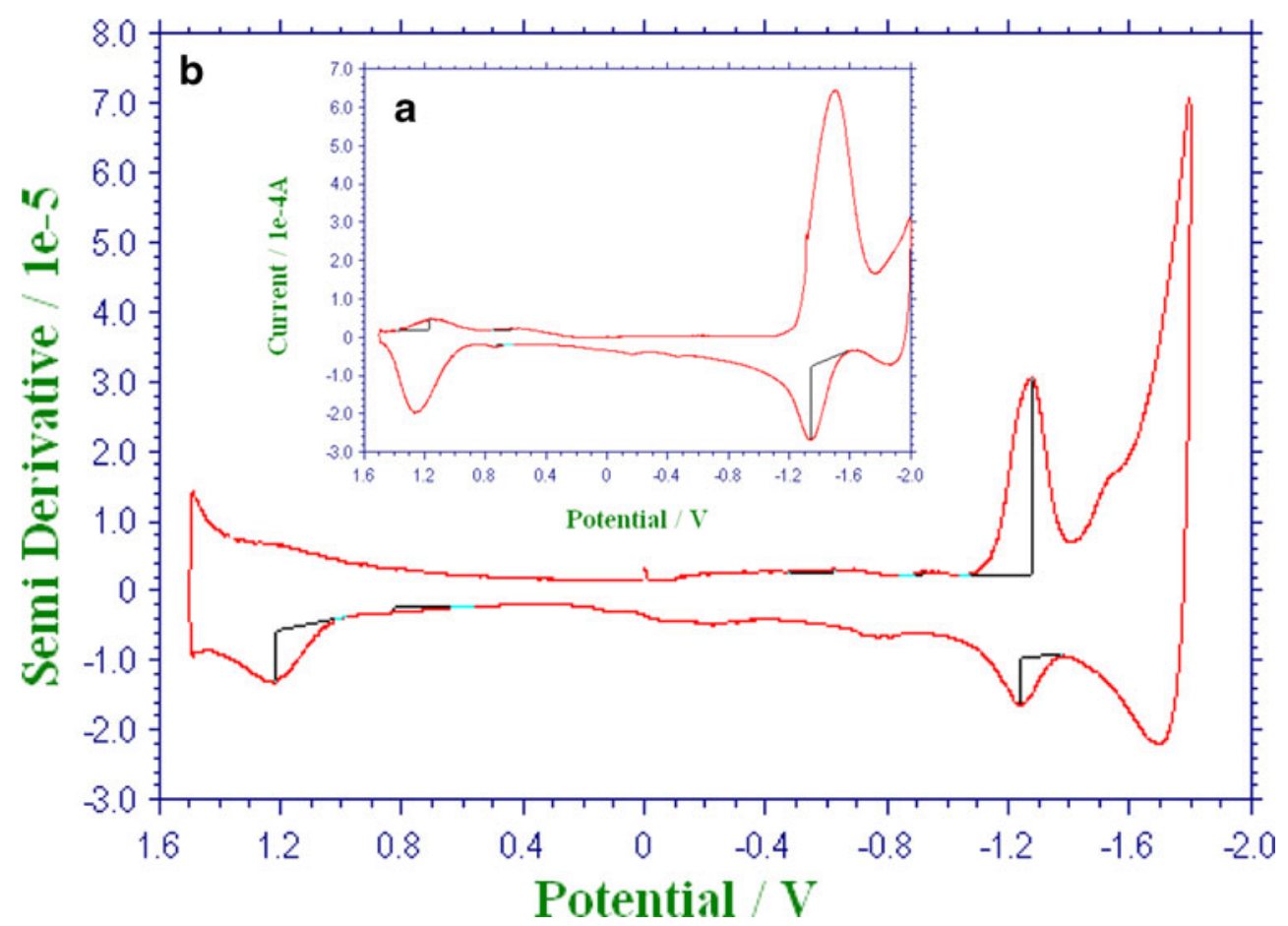


Table $2 \mathrm{E}_{\mathrm{Lumo}}$ and $\mathrm{E}_{\mathrm{HOMO}}$ energy levels of synthesized NI and NB derivatives

$\mathrm{E}_{\text {ferrocene }}=0.39 \mathrm{~V}$ (Ferrocene is internal reference electrode)

$\mathrm{E}_{0}-\mathrm{E}_{-1}=$ Reduction potentials of synthesized derivatives

\begin{tabular}{lcccc}
\hline & $\mathrm{E}_{0}-\mathrm{E}_{-1}$, Volt & $\mathrm{E}_{\text {LUMO }}, \mathrm{eV}$ & $\mathrm{E}_{\text {HOMO, }} \mathrm{eV}$ & Band Gap, eV \\
\hline NI_I & -1.34 & 3.07 & 5.51 & 2.44 \\
NI_II & -1.39 & 3.02 & 5.59 & 2.57 \\
NB_I & -1.26 & 3.15 & 5.62 & 2.47 \\
NB_II & -1.14 & 3.28 & 5.57 & 2.29 \\
\hline
\end{tabular}

\section{Experimental}

\section{Materials}

1,8-Naphthalic anhydride, 2-ethyl hexyl amine, butyl amine, $o$-phenylene diamine, 3,4-diamino pyridine, anthracene were purchased from Aldrich. Quinine sulfate was supplied from Acros Organics. The fluorescence quantum yields of naphthalene benzimidazoles were measured using quinine sulfate as the reference compound ( $\varphi \mathrm{f}=0.546$ in $\left.1 \mathrm{~N} \mathrm{H}_{2} \mathrm{SO} 4\right)$.

All solvents were of spectroscopic grade and were used without any further purification.

\section{Materials Characterization}

The UV-vis absorption spectra were recorded in an Analytic JENA S 600. Fluorescence spectra were obtained in a PTI QM1 fluorescence spectrophotometer. Concentrations were arranged to $10^{-6} \mathrm{M}$ in order to avoid aggregation or reabsorption effects for absorption, fluorescence and quantum yield measurements. Quinine sulfate was used as the fluorescence quantum yield standard for naphthalene benzimidazole and 1,8-naphthalene(3,4-pyridine imidazole). Anthracene was used as the fluorescence quantum yield standard for naphthalene imides. Cyclic voltammetry measurements of synthesized naphthalimide and naphthalene benzimidazole derivatives were taken using CH-Instrument 660 B Model Potentiostat equipment. Thermal stabilities were determined by means of thermal gravimetry measurements (TGA) with the equipment of Perkin Elmer- Thermogravimetric Analyzer Pyris 6 TGA.

Synthesis and Characterization of Naphthalimide (NI) and Naphthalene Benzimidazole (NB) Derivatives

A microwave oven, CEM MARS-5, frequency $2.45 \mathrm{GHz}$, maximum power $700 \mathrm{~W}$, was used to synthesize naphthalimide and naphthalene benzimidazole derivatives. Naphthalimides and naphthalene benzimidazoles have been synthesized by condensation reaction of 1,8-naphthalic anhydride and primary amine or $o$-phenylene diamine in imidazole solutions, using microwave oven. 1,8-Naphthalic anhydride ( $1 \mathrm{~g}, 0.005 \mathrm{~mol})$, a primary amine $(0.36 \mathrm{~g}$, $0.005 \mathrm{~mol})$ or $o$-phenylene diamine $(0.55 \mathrm{~g}, 0.005 \mathrm{~mol})$ and imidazole (10 g) were placed in to XP-1500-plus vessel of microwave oven. The reaction has been completed in 20 min which was found to be an optimum time. After $20 \mathrm{~min}$, solution was cooled and treated with $2 \mathrm{~N}$ of $\mathrm{HCl}$ to remove excess imidazole. Then, the material was filtered and washed with water. The crude product was purified by silicagel column chromatography, using $\mathrm{CH}_{2} \mathrm{Cl}_{2}$ as eluent. The reaction yield is $90 \%$ for naphthalimide (white color); $85 \%$ for naphthalene benzimidazole (yellow color) for microwave heating method. Solubility of N-butyl-1,8naphthalimide is $300 \mathrm{mg} / \mathrm{ml}$ in $\mathrm{CH}_{2} \mathrm{Cl}_{2}, \mathrm{~N}$-2-ethyl hexyl1,8-naphthalimide is $450 \mathrm{mg} / \mathrm{ml}$ in $\mathrm{CH}_{2} \mathrm{Cl}_{2}$; solubility of 1,8-naphthalene benzimidazole is $60 \mathrm{mg} / \mathrm{ml}$ in $\mathrm{CH}_{2} \mathrm{Cl}_{2}$. solubility of 1,8-Naphthalene(3,4-pyridine imidazole) is $40 \mathrm{mg} / \mathrm{ml}$ in $\mathrm{CH}_{2} \mathrm{Cl}_{2}$. Materials were characterized using ${ }^{1} \mathrm{H}-\mathrm{NMR}$, IR and Elemantal Analysis.

-N-Butyl-1,8-naphthalene imide; NI_I, IR (KBr): $\mathrm{cm}^{-1}$, $3050,2950,1700,1650,1575,1455,1380,1250,1190$, 1085, 990, 880, 750 .

${ }^{1} \mathrm{H} \mathrm{NMR}\left(\mathrm{CDCl}_{3}\right),(\mathrm{ppm}), 8.6(2 \mathrm{H}, \mathrm{s}), 8.2(2 \mathrm{H}, \mathrm{s}), 7.7(2 \mathrm{H}$, s), 4.3(2H, m), 1.7(2H, m), 1.45(2H, m), $1.0(3 \mathrm{H}, \mathrm{m})$.

$\mathrm{C}_{16} \mathrm{H}_{15} \mathrm{NO}_{2}$ (253): Calcd: C 75.87\%, H 5.97\%, N $5.53 \%$, O $12.63 \%$; found: C $75.88 \%$, H 5.99\%, N 5.52\%, O $12.64 \%$.

-N-2-Ethyl hexyl-1,8-naphthalene imide, NI_II, IR (KBr): $\mathrm{cm}^{-1}, 3063,2957,2924,2872,2856,1700,1654$, $1625,1590,1534,1498,1512,1459,1438,1416,1388$, $1346,1318,1278,1236,1205,1185,1168,1133,1083$, 1073, 1026, 949, 916, 900, 857, 847, 799, 783, 738.

${ }^{1} \mathrm{H}$ NMR $\left(\mathrm{CDCl}_{3}\right):(\mathrm{ppm}), 8.6(2 \mathrm{H}, \mathrm{s}), 8.2(2 \mathrm{H}, \mathrm{s}), 7.6$ (2H, s), $4.1(2 \mathrm{H}, \mathrm{m}), 1.9(\mathrm{H}, \mathrm{m}), 1.3(8 \mathrm{H}, \mathrm{m}), 0.9(6 \mathrm{H}, \mathrm{m})$.

$\mathrm{C}_{20} \mathrm{H}_{23} \mathrm{NO}_{2}$ (309): Calcd: C 77.64\%, H 7.49\%, N $4.53 \%$, O $10.34 \%$; found: C $77.65 \%$, H $7.51 \%$, N 4.53\%, O $10.34 \%$.

-1,8-Naphthalene benzimidazole, NB_I, IR ( $\mathrm{KBr})$ : $\mathrm{cm}^{-1}, 3060,1696,1671,1640,1618,158 \overline{3}, 1551,1501$, $1449,1362,1322,1289,1230,1177,1150,1122,1072$, 1029, 917, 880, 840, 750, 700, 670, 617.

${ }^{1} \mathrm{H}$ NMR $\left(\mathrm{CDCl}_{3}\right)$ : (ppm), $8.80(2 \mathrm{H}, \mathrm{d}), 8.56(\mathrm{H}, \mathrm{m}), 8.26$ (H, d), 8.12 (H, d), $7.88(\mathrm{H}, \mathrm{m}), 7.78(2 \mathrm{H}, \mathrm{m}), 7.48(2 \mathrm{H}, \mathrm{m})$.

$\mathrm{C}_{18} \mathrm{H}_{10} \mathrm{~N}_{2} \mathrm{O}$ (270): Calcd: C 79.99\%, H 3.73\%, N $10.36 \%$, O $5.92 \%$; found: C $79.96 \%, \mathrm{H} 3.75 \%, \mathrm{~N}$ $10.36 \%$, O $5.93 \%$.

-1,8-Naphthalene(3,4-pyridine imidazole), NB_II, IR (KBr): $\mathrm{cm}^{-1}, 3057,1700,1640,1619,1540,1500,1440$, 1362, 1327, 1261, 1236, 1181, 1140, 1031, 819, 770, 601. 
a)

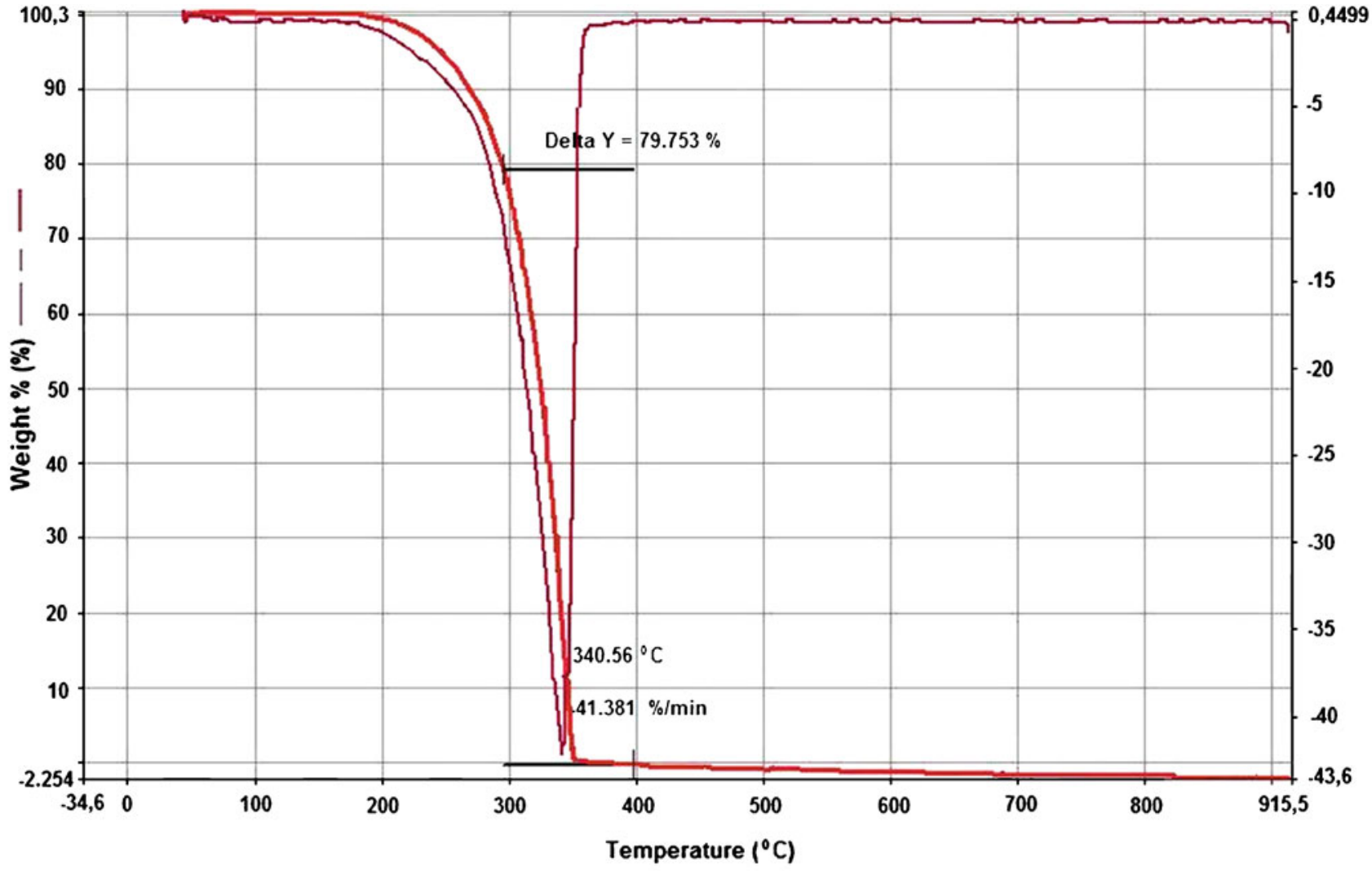

b)

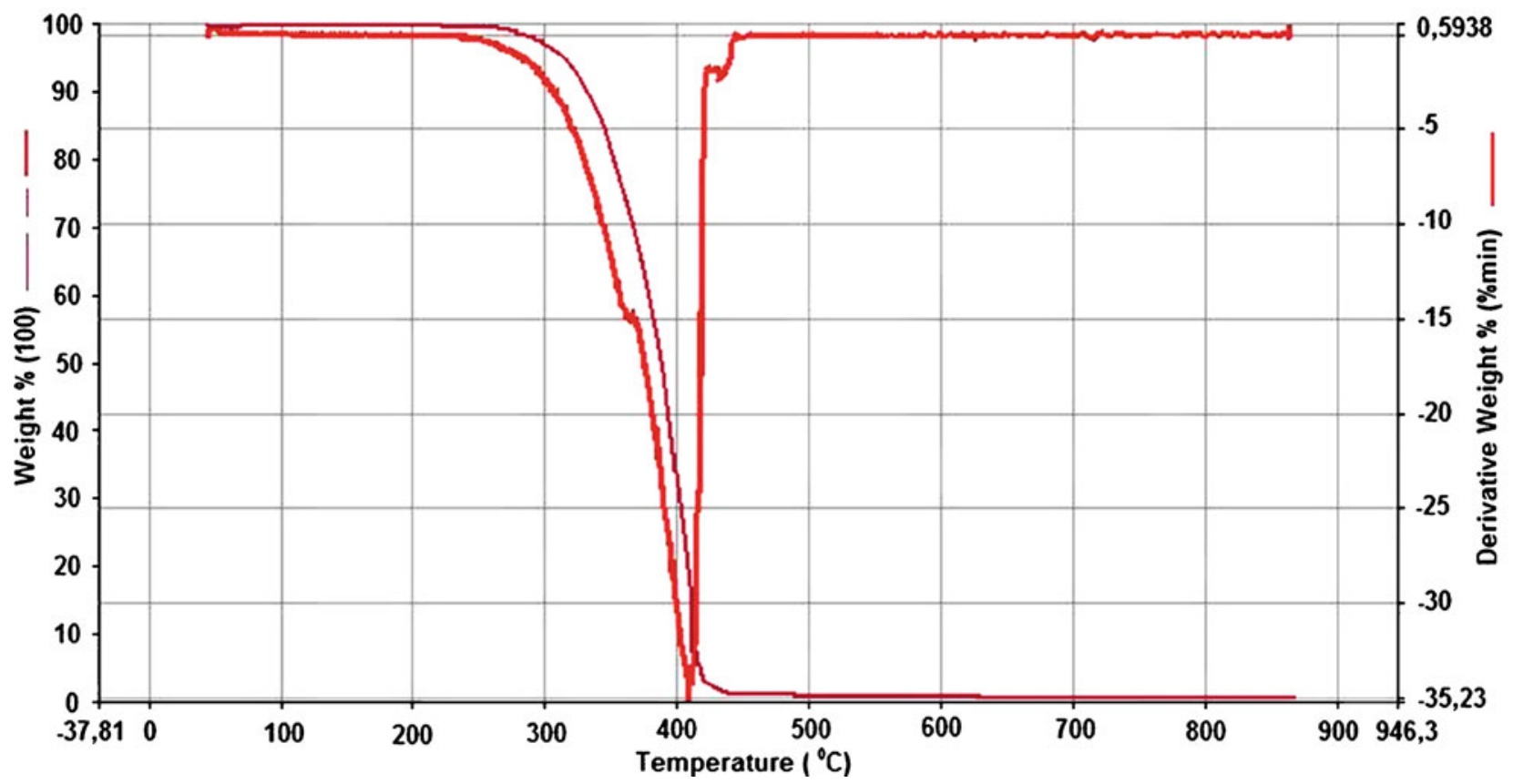

Fig. 2 TGA curve of NI_II (a), and NB_I (b) 
Table 3 UV/Vis spectroscopy data and Fluorescence emission maxima of NI_I and NI_II in dichloromethane, DMF, Acetonitrile, THF, Hexane, Methanol

\begin{tabular}{|c|c|c|c|c|c|c|c|c|c|c|c|}
\hline & & $\varepsilon$ & $\begin{array}{l}\text { Refraction } \\
\text { index }\end{array}$ & $\lambda_{1}(\mathrm{~nm})$ & $\varepsilon_{1}\left(\mathrm{M}^{-1} \mathrm{~cm}^{-1}\right)$ & $\lambda_{2}(\mathrm{~nm})$ & $\varepsilon_{2}\left(\mathrm{M}^{-1} \mathrm{~cm}^{-1}\right)$ & $\lambda_{3}(\mathrm{~nm})$ & $\varepsilon_{3}\left(\mathrm{M}^{-1} \mathrm{~cm}^{-1}\right)$ & $\lambda_{\mathrm{f}}^{\max }(\mathrm{nm})$ & $\begin{array}{l}\text { Stokes } \\
\text { shift } \\
\left(\mathrm{cm}^{-1}\right)\end{array}$ \\
\hline \multirow[t]{6}{*}{ NI_I } & Acetonitrile & 37.5 & 1.3441 & 318 & 11767 & 332 & 16098 & 348 & 14359 & 380 & 1190 \\
\hline & $\mathrm{DMF}$ & 36.7 & 1.4303 & 318 & 13460 & 334 & 18755 & 349 & 16456 & 384 & 1410 \\
\hline & Dichloromethane & 8.93 & 1.4242 & 319 & 17050 & 334 & 24000 & 344 & 21875 & 383 & 1600 \\
\hline & THF & 7.6 & 1.4076 & 318 & 10632 & 332 & 14178 & 345 & 12552 & 377 & 1210 \\
\hline & Hexane & 1.87 & 1.372 & 312 & 9202 & 326 & 12474 & 342 & 12308 & 364 & 590 \\
\hline & Methanol & 33.1 & 1.326 & 316 & 7182 & 333 & 10651 & 343 & 10167 & 384 & 2417 \\
\hline \multirow[t]{6}{*}{ NI_II } & Acetonitrile & 37.5 & 1.3441 & 317 & 9130 & 332 & 12640 & 347 & 11940 & 382 & 1570 \\
\hline & DMF & 36.7 & 1.4303 & 320 & 10945 & 334 & 14810 & 349 & 13520 & 384 & 1630 \\
\hline & Dichloromethane & 8.93 & 1.4242 & 320 & 11235 & 334 & 15450 & 349 & 13340 & 381 & 1330 \\
\hline & THF & 7.6 & 1.4076 & 318 & 9440 & 332 & 13730 & 347 & 12015 & 378 & 1190 \\
\hline & Hexane & 1.87 & 1.372 & 312 & 8101 & 328 & 10695 & 343 & 10378 & 368 & 910 \\
\hline & Methanol & 33.1 & 1.326 & 316 & 6718 & 333 & 9656 & 343 & 9046 & 387 & 2200 \\
\hline
\end{tabular}

$\lambda_{\mathrm{f}}^{\max }, \mathrm{nm}$, fluorescence emission maxima

$\varepsilon_{1}, \mathrm{M}^{-1} \mathrm{~cm}^{-1}$, molar extinction coefficient

${ }^{1} \mathrm{H}$ NMR $\left(\mathrm{CDCl}_{3}\right)$ : $(\mathrm{ppm}), 9.24(\mathrm{H}, \mathrm{s}), 8.90(\mathrm{H}, \mathrm{d}), 8.82$ $(\mathrm{H}, \mathrm{d}), 8.68(\mathrm{H}, \mathrm{d}), 8.50(\mathrm{H}, \mathrm{d}), 8.35(\mathrm{H}, \mathrm{d}), 8.24(\mathrm{H}, \mathrm{d}), 7.86$ $(2 \mathrm{H}, \mathrm{m})$.

$\mathrm{C}_{17} \mathrm{H}_{9} \mathrm{~N}_{3} \mathrm{O}$ (271): Calcd: C $75.27 \%, \mathrm{H} 3.34 \%, \mathrm{~N}$ $15.49 \%$, O $5.90 \%$; found: C $75.26 \%, \mathrm{H} 3.34 \%, \mathrm{~N}$ $15.50 \%$, O $5.92 \%$.

Electrochemistry of Naphthalimide (NI) and Naphthalene Benzimidazole (NB) Derivatives

$\mathrm{E}_{\mathrm{HOMO}}$ and $\mathrm{E}_{\mathrm{LUMO}}$ values of NIs and NBs were calculated using cyclic voltammograms with scan rates in the range of
$100-500 \mathrm{mV} / \mathrm{s}$ under nitrogen at $25^{\circ} \mathrm{C}$. Solutions of NI and NB derivatives were prepared in chloroform $\left(10^{-3} \mathrm{M}\right)$. A three electrode cell was used consisting of glassy carbon working electrode, $\mathrm{Pt}$ wire counter electrode and $\mathrm{Ag} / \mathrm{AgCl}$ reference electrode, all placed in a glass vessel. Tetrabutylamonium hexafluorophosphate $\left(\mathrm{TBAPF}_{6}\right), 0.1 \mathrm{M}$, was used as supporting electrolyte. Ferrocene was used as internal reference electrode. NI and NB derivatives show both quasi-reversible reduction and oxidation potential in Fig. 1. In calculation, the zero vacuum level of ferrocene was taken as $4.8 \mathrm{eV}[21,22]$. We used the following equation to calculate $\mathrm{E}_{\mathrm{HOMO}}$ and $\mathrm{E}_{\mathrm{LUMO}}$ energy level of

Table 4 UV/Vis spectroscopy data and fluorescence emission maxima of NB_I and NB_II in dichloromethane, DMF, Acetonitrile, THF, Hexane, Methanol

\begin{tabular}{|c|c|c|c|c|c|c|c|c|c|}
\hline & & $\varepsilon$ & Refraction index & $\lambda_{1}(\mathrm{~nm})$ & $\varepsilon_{1}\left(\mathrm{M}^{-1} \mathrm{~cm}^{-1}\right)$ & $\lambda_{2}(\mathrm{~nm})$ & $\varepsilon_{2}\left(\mathrm{M}^{-1} \mathrm{~cm}^{-1}\right)$ & $\lambda_{\mathrm{f}}^{\max }(\mathrm{nm})$ & Stokes shift $\left(\mathrm{cm}^{-1}\right)$ \\
\hline \multirow[t]{6}{*}{ NB_I } & Acetonitrile & 37.5 & 1.3441 & 331 & 6840 & 379 & 12435 & 492 & 6060 \\
\hline & DMF & 36.7 & 1.4303 & 331 & 6080 & 383 & 9965 & 490 & 5700 \\
\hline & Dichloromethane & 8.93 & 1.4242 & 333 & 10135 & 385 & 15710 & 488 & 5560 \\
\hline & THF & 7.6 & 1.4076 & 333 & 7980 & 382 & 13480 & 485 & 5480 \\
\hline & Hexane & 1.87 & 1.3720 & 343 & 6523 & 380 & 10590 & 470 & 4010 \\
\hline & Methanol & 33.1 & 1.3260 & 344 & 8693 & 382 & 13295 & 499 & 6140 \\
\hline \multirow[t]{6}{*}{ NB_II } & Acetonitrile & 37.5 & 1.3441 & 347 & 8808 & 374 & 12466 & 469 & 5420 \\
\hline & DMF & 36.7 & 1.4303 & 348 & 12602 & 378 & 17791 & 470 & 5180 \\
\hline & Dichloromethane & 8.93 & 1.4242 & 350 & 12873 & 380 & 18713 & 464 & 4760 \\
\hline & THF & 7.6 & 1.4076 & 347 & 10276 & 375 & 13800 & 464 & 5110 \\
\hline & Hexane & 1.87 & 1.3720 & 347 & 7826 & 373 & 9990 & 455 & 3870 \\
\hline & Methanol & 33.1 & 1.3260 & 350 & 10263 & 372 & 13151 & 450 & 4660 \\
\hline
\end{tabular}

$\lambda_{\mathrm{f}}^{\max }, \mathrm{nm}$, fluorescence emission maxima

$\varepsilon_{1}, \mathrm{M}^{-1} \mathrm{~cm}^{-1}$, molar extinction coefficient 
Table 5 Fluorescence emission maxima and quantum yield of naphthalimides and naphthalene benzimidazoles, in acetonitrile

\begin{tabular}{lcc}
\hline & $\lambda_{\mathrm{f}}^{\max }(\mathrm{nm})$ & $\Phi_{\mathrm{f}}($ Quantum yield $)$ \\
\hline NI_I & 380 & 0.018 \\
NI_II & 380 & 0.011 \\
NB_I & 492 & 0.36 \\
NB_II & 469 & 0.60 \\
\hline
\end{tabular}

$\lambda_{\mathrm{f}}^{\max }, \mathrm{nm}$, fluorescence emission maxima

$\phi_{\mathrm{f}}$, Quantum yield

NIs and NBs, $E_{L U M O}=-e\left(E_{1 / 2(\text { redox })}-E_{f e r}\right)+4.8$ [19]. $\mathrm{E}_{\mathrm{HOMO}}$ and $\mathrm{E}_{\mathrm{LUMO}}$ energy levels of NI and NB derivatives are found to be in between 5.51 and $5.62 \mathrm{eV}$ and 3.02 and $3.28 \mathrm{eV}$, respectively. The $\mathrm{CV}$ values are presented in Table 2. E EUMO energy levels of naphthalene benzimidazole derivatives are higher than the conduction band of $\mathrm{TiO}_{2}, \mathrm{E}_{\mathrm{CB}}\left(\mathrm{TiO}_{2}\right)=4.2 \mathrm{eV}$. Naphthalene benzimidazole derivatives absorb in the visible region. They are promising materials for organic photovoltaics [21, 22].

\section{Results and Discussion}

Thermal Stabilities of Naphthalimide (NI) and Naphthalene Benzimidazole (NB) Derivatives

Thermal stabilities of synthesized compounds are determined using thermal gravimetry measurements. TGA curves of NI_II and NB_I are presented in Fig. 2. Naphthalene benzimidazole derivatives are found to be more stable than naphthalimide derivatives. Decomposition temperature of naphthalimides starts from $200{ }^{\circ} \mathrm{C}$ and ends at $341{ }^{\circ} \mathrm{C}$, Fig. 2

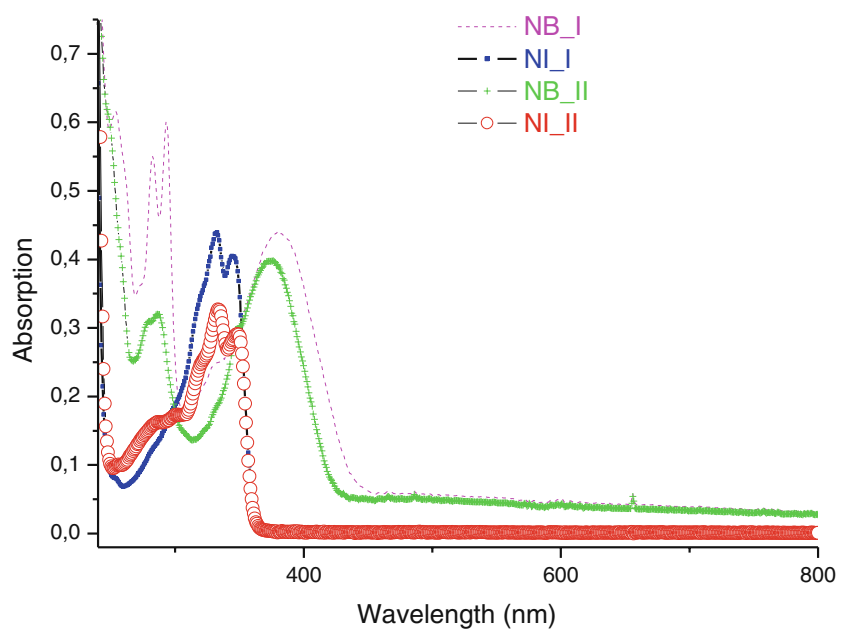

Fig. 3 Absorption spectra of N-butyl-1,8-naphthalimide, NI I; N-2ethylhexyl-1,8-naphthalimide, NI II; 1,8-naphthalene benzimidazole, NB_I; 1,8-naphthalene(3,4-pyridine imidazole), NB_II, in acetonitrile (a); the temperature range for naphthalene benzimidazoles is between $300{ }^{\circ} \mathrm{C}$ and ends at $415{ }^{\circ} \mathrm{C}$, Fig. 2(b). Naphthalene benzimidazole derivatives have high thermal stabilities, pointing their favorability in photovoltaic applications.

Absorption and Fluorescence Emission of Naphthalimide (NI) and Naphthalene Benzimidazole (NB) Derivatives

The UV-vis absorption spectra and fluorescence emission spectra of NI and NB derivatives have been studied in various solvents of different polarity and the spectral data have been collected in Table 1. UV-vis Absorption and fluorescence emission spectrs of NI and NB derivatives were taken in acetonitrile, DMF, dichloromethane, THF, methanol and hexane in Figs. 5 and 6. Quantum yields were calculated using fluorescence quantum yield standards. Excitation wavelengths of NIs and NBs are determined as $333 \mathrm{~nm}$ and $350 \mathrm{~nm}$, respectively. Fluorescence quantum yields of the NIs and NBs, measured in acetonitrile, are collected in Table 5. Among compounds, N-butyl and N-2-ethylhexyl substituted naphthalimides give three characteristic band at $320 \mathrm{~nm}, 334 \mathrm{~nm}, 349 \mathrm{~nm}$ in Table 3.
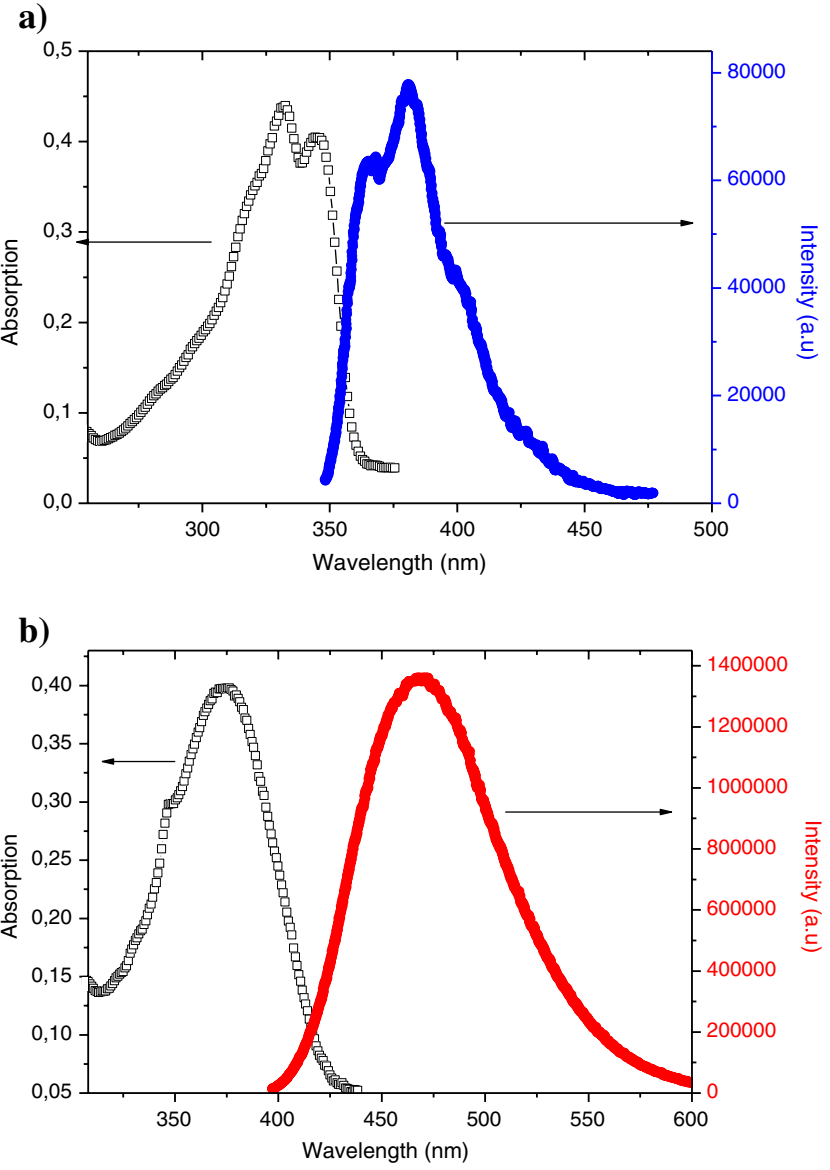

Fig. 4 Absorption and Fluorescence emission spectra of NI_II (a) and NB_II (b) in acetonitrile (Mirror Image) 
$\mathrm{N}$-substituted 1,8-naphthalimides have a wavelength of maximum fluorescence emission $\left(\lambda_{\mathrm{f}}^{\max }\right)$ of $380 \mathrm{~nm}$ in Table 5. Absorption bands of naphthalene benzimidazole and 1,8-naphthalene(3,4-pyridine imidazole) range from $300 \mathrm{~nm}$ to $430 \mathrm{~nm}$ in different solvents, Table 4. As shown in Table 5, NB I and NB II have wavelengths of maximum emissions of $469 \mathrm{~nm}$ and $492 \mathrm{~nm}$. The results show that electron-donating substituents such as phenylene onto naphthalimide moities had very strong influence on the absorption, fluorescence emission and lead to a red-shifted phenomena.

$\mathrm{N}$-butyl and N-2-ethylhexyl-1,8-napthalimides display a weak fluorescence quantum yields; $\Phi_{\mathrm{f}}=0.018$ and 0.011 , respectively. In agreement with literature data, E. Martin et al. and V. Wintgens et al. have reported that the low value of fluorescence quantum efficiency for naphthalimides is associated to an effective intersystem crossing (ISC) between the singlet excited state $\mathrm{S}_{1}$ and the nearby triplet state; the ISC efficiency is reported around 0.95 and 1.0 in acetonitrile and hexane solution, respectively [21-23]. On the other hand, 1,8-naphthalene benzimidazole having an electrondonating substituent are highly fluorescent. The presence of a conjugated electron-

a)

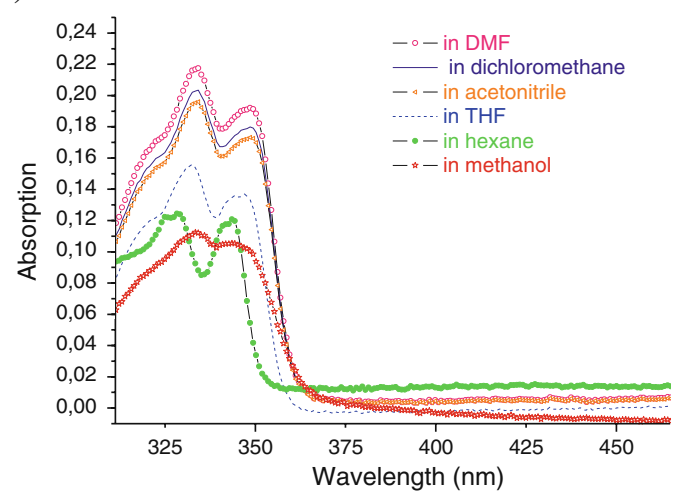

b)

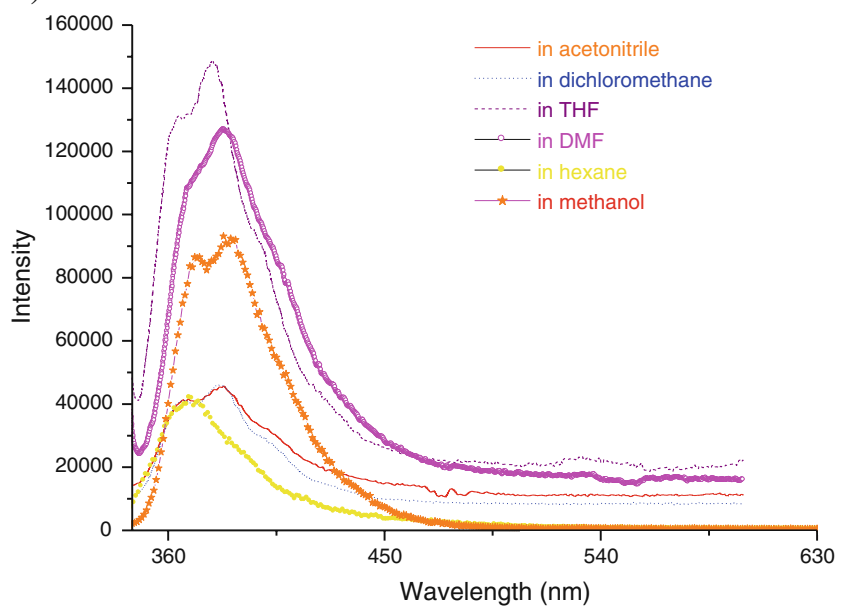

Fig. 5 Absorption (a) and Fluorescence Emission (b) spectra of N-2ethylhexyl-1,8-Naphthalimide, NI_II in different solvents donor group condensed onto the naphthalimide moiety alters the emission spectra considerably (Figs. 5 and 6). These substituents cause high red-shifts in fluorescence spectra $\left(\Delta \lambda^{f}: 89-112 \mathrm{~nm}\right)$ and substantially increase the fluorescence yields $\left(\Phi_{\mathrm{f}}\right)$ from $0.011,0.018$ to $0.36,0.60$, (Figs. 3, 4 and Table 5). NB_I shows higher fluorescence quantum yield of 0.36 , with respect to naphthalimides of NI_I and NI_II, a clear observation of enhanced conjugation effect by phenylene ring condensation. Highest quantum yield observed for NB_II $\left(\Phi_{\mathrm{f}}=0.60\right)$. The presence of electron donating substituents may also increase the separation between the singlet $\left(\mathrm{S}_{1}\right)$ and its closer triplet excited state, thus decreasing the intersystem crossing (ISC) and favoring the fluorescence deactivation channel [24-32] (Figs. 5 and 6).

The band position of Absorption and emission spectra for NIs and NBs depend on the change in solvent's polarity.

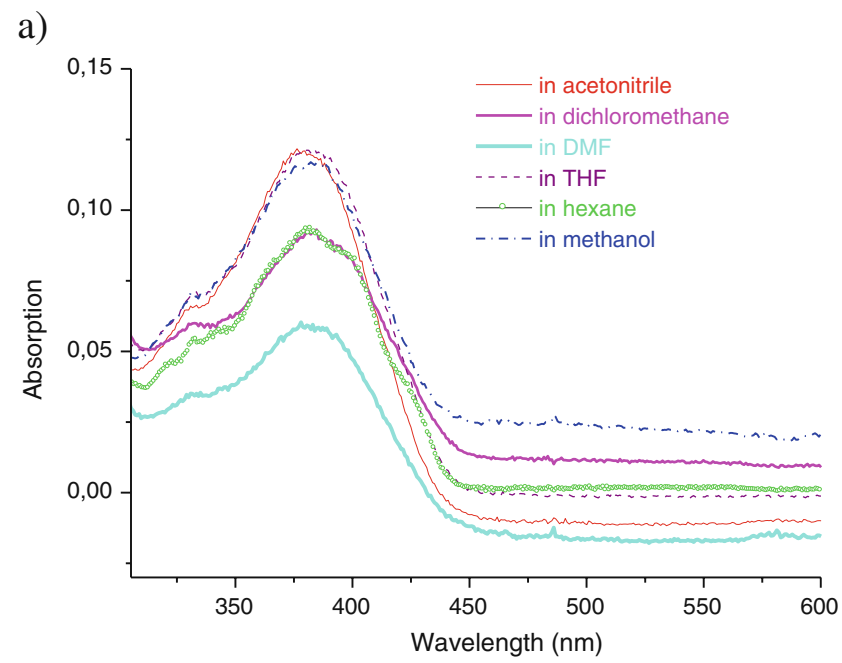

b)

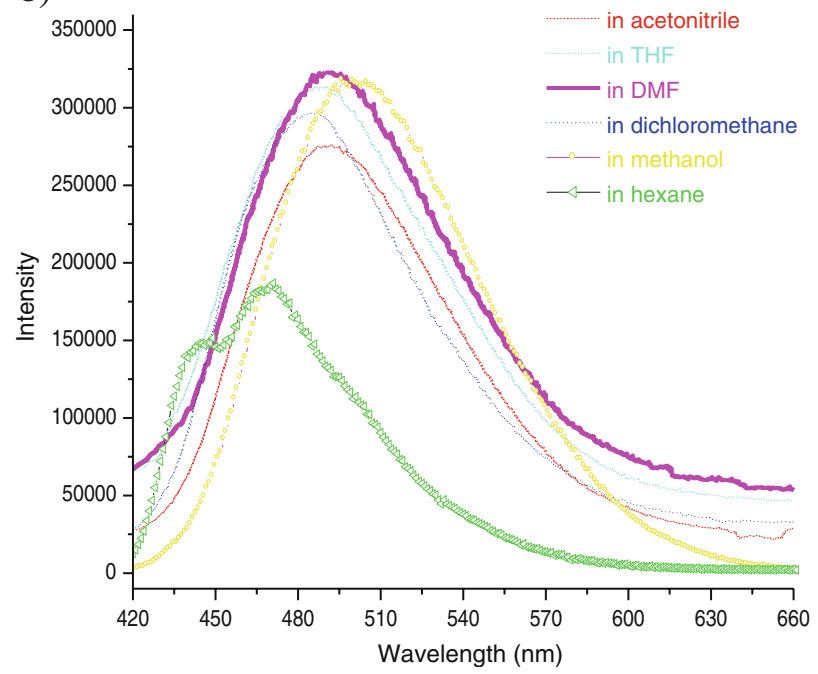

Fig. 6 Absorption (a) and Fluorescence emission (b) spectra of 1,8naphthalene benzimidazole, NB_I in different solvents 
Fig. 7 Effects of solvent polarity in the Stokes' shift of NIs and NBs in the solvents $(\mathbf{a}, \mathbf{b}, \mathbf{c}$, d). The numbers refer to the following solvents: 1 , hexane; 2 , THF; 3, dichloromethane; 4, DMF; 5 , acetonitrile; 6 , methanol

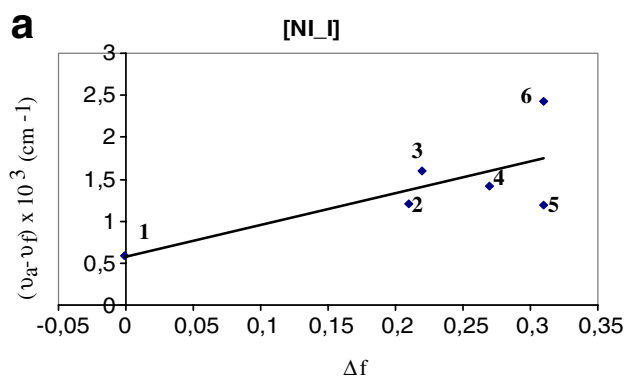

b

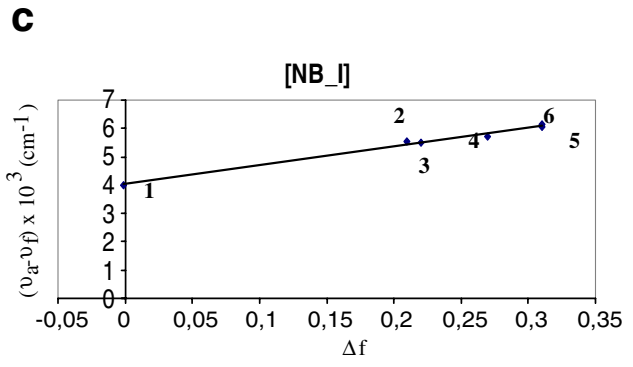

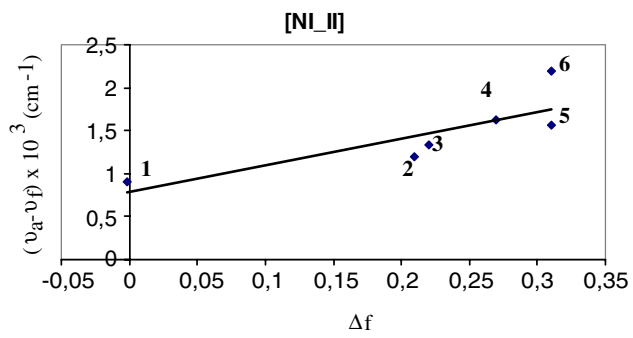

d

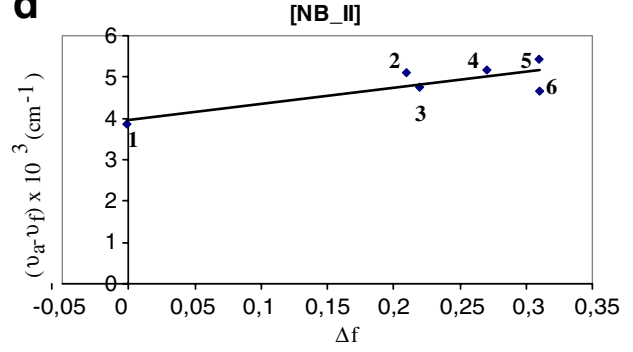

We also tried to examine the effect of solvent's polarity on the molecular structures. The Absorption bands of naphthalimides are revealed an influence of the solvent's polarity. The solvent effects the characteristics of the spectra of solute molecules. The responses of NI and NB derivatives to solvent polarity can be analyzed in terms of the difference in the dipole moments in the ground and excited states. This can also be further estimated from a Lippert-Mataga plot (Fig. 7), which is essentially a plot of the Stokes shift of the fluorescence emission vs the solvent polarity. The difference in the maximum absorption and emission wavelengths, expressed in wavenumbers $(\Delta \bar{U})$, is fitted to the following equation. The difference between the maximum absorption and emission wavelengths, expressed in wavenumbers $(\nu \mathrm{a}-\nu \mathrm{f})$, is correlated with the solvent polarity parameter $\left(\Delta_{\mathrm{f}}\right)$.

$\bar{U}_{a}-\bar{U}_{f}=\frac{2\left(\mu_{e}-\mu_{g}\right)^{2}}{h c a^{3}} \Delta f+$ constant

Where, $\mu \mathrm{e}-\mu \mathrm{g}$ is the difference $(\Delta \mu)$ between the dipole moments of the excited and the ground states, respectively, $c$ is the velocity of light, and $\mathrm{R}$ is the radius of the Onsager cavity around the fluorophore. The parameters $\varepsilon$ and $n$ are the solvent dielectric constant and refraction index, respectively, which are grouped in the term $\Delta f$, known as orientation polarizability. A plot of $\Delta \bar{U}$ versus $\Delta_{\mathrm{f}}$ gives $\Delta \mu[33-35]$.

$\Delta f=\frac{\varepsilon-1}{2 \varepsilon+1}-\frac{n^{2}-1}{2 n^{2}+1}$

The linearity of these plots is often regarded as evidence for the dominant importance of general solvent effects in spectral shifts. Specific solvent effects lead to nonlinear Lippert Plots. General solvent effects are due to the interactions of the dipole of the fluorophore with its environment. Specific solvent effects is because of fluorophore-solvent interactions and specific effects can be due to hydrogen bonding or charge-transfer interactions. Stokes' shifts for NI and NB derivatives have been calculated in various solvents of different polarity and the data have been collected in Tables 3 and 4. As a result, it is found that Lippert curves for NI derivatives are non-linear, Lippert curves for naphthalene benzimidazoles are linear (Fig. 7).

\section{Conclusion}

In conclusion, thermal-stable naphthalene benzimidazoles were successfully synthesized. Absorption and emission spectra were studied in different solvents. Moreover, it was observed that phenylene groups onto naphthalimide moiety effect the Absorption and emission wavelengths, quantum yields, thermal stabilities and electrochemistry of naphthalene benzimidazoles. Naphthalene benzimidazole compounds may serve as good light-emitting materials, because they emit light in the range of $420 \mathrm{~nm}-630 \mathrm{~nm}$. $\mathrm{E}_{\mathrm{LUMO}}$ values of naphthalene benzimidazoles are found to be between 3.15 and $3.28 \mathrm{eV}$. Naphthalene benzimidazole derivatives can inject electrons to the conduction band of titanium dioxide in dye sensitized solar cell. Naphthalene benzimidazole derivatives are also promising materials in organic solar cells.

Acknowledgements We acknowledge financial support from Scientific and Technological Research Council of Turkey, TUBITAK, 
TBAG_106T061 and the Alexander von Humboldt Foundation of Germany and European Science Foundation (ESF) for research supports. I thank Mechanical Engineer DI. Cagatay Ela for proofreading.

\section{References}

1. Bailly C, Carrasco C, Joubert A, Bal C, Wattez N, Hildebrand MP, Lansiaux A, Colson P, Houssier C, Cacho M, Ramos A, Brãna MF (2003) Biochemistry 42:4136

2. Brãna MF, Ramos A (2001) Curr Med Chem Anticancer Agents 1:237

3. Zsombor M, József N, László B, Krisztina SN, Tamás K (2006) J Photochem Photobiol, A 99:182

4. Settimo AD, Primofiore G, Ferrarini PL, Ferretti M, Barili PL, Tellini N, Bianchini P (1989) Eur J Med Chem 24:263

5. Saito I (1992) Pure Appl Chem 64:1305

6. Kirshenbaum MR, Chen SF, Behrens CH, Papp LM, Stafford MM, Sun JH, Behrens DL, Fredericks JR, Polkus ST, Sipple P, Patten AD, Dexter D, Seitz SP, Gross JL (1994) Cancer Res 54:2199

7. Dorlars A, Schellhammer CW, Schroeder J (1975) Angew Chem Int Ed Engl 14:665

8. Stewart WW (1981) Nature 292:17

9. Brana MF, Castellano JM, Roldan CM, Santos A, Vazquez D, Jimenez A (1980) Cancer Chemother Pharmacol 4:61

10. Braña MF, Castellano JM, Morán M, Pérez de Vega MJ, Qian XD, Romerdahl CA, Keilhauer G (1995) Eur J Med Chem 30:235

11. Chatterjee S, Pramanik S, Hossain SU, Bhattacharya S, Subhash Bhattacharya C (2007) J Photochem Photobiol, A 187:64

12. Xuhong Q, Zhenghua Z, Kongchang C (1989) Dyes Pigm 11:13

13. Marling JB, Hawley JG, Liston EM, Grant WB (1974) Appl Opt 13:2317

14. Grabchev I, Moneva I, Bojinov V, Guittonneau S (2000) J Mater Chem 10:1291
15. Pardo A, Martin E, Poyato JML, Camacho JJ, Guerra JM, Weigand R, Braña JMF, Castellano JM (1989) J Photochem Photobiol, A 48:259

16. Martin E, Weigand R, Pardo A (1996) J Lumin 68:157

17. Singh ThB, Erten S, Gunes S, Zafer C, Turkmen G, Kuban B, Teoman Y, Sariciftci NS, Icli S (2006) Org Electron 7:480

18. Plakidin VL, Kosheleva ES (1975) Zhur Organ Khim 11:1512

19. Jiang W, Tang J, Qi Q, Sun Y, Ye H, Fu D (2009) Dyes Pigm 3:279

20. Martin E, Coronado JLGu, Camacho JJ, Pardo A (2005) J Photochem Photobiol, A 175:1

21. Erten S, Eren E, Icli S (2007) Eur Phys J Appl Phys 38:227

22. Erten S, Icli S (2008) Inorg Chim Acta 361:595

23. Wintgens V, Valat P, Kossanyi J, Demeter A, Biczok L, Berces T (1996) New J Chem 20:1149

24. Lee CM, Kumler WD (1962) J Org Chem 27:2055

25. Berci FP, Toscano VG, Politi MJ (1988) J Photochem Photobiol, A $43: 51$

26. Almeida FCL, Toscano VG, Dos Santos O, Politi MJ, Neumann MG, Berci Filho P (1991) J Photochem Photobiol, A $58: 289$

27. Wintgens V, Valat P, Kossanyi J, Biczok L, Demeter A, Bérces T (1994) J Chem Soc, Faraday Trans 90:411

28. Brochsztain S, Rodrigues MA, Politi MJ (1997) J Photochem Photobiol, A Chem 107:195

29. Barros TC, Molinari GR, Berci Filho P, Toscano VG, Politi MJ (1993) J Photochem Photobiol, A Chem 76:55

30. Demets GJ-F, Triboni ER, Alvarez EB, Arantes GM, Filho PB, Politi MJ (2006) Spectrochim Acta A 63:220-226

31. Niu CG, Qin PZ, Zeng GM, Gui XQ, Guan AL (2007) Anal Bioanal Chem 387:1067

32. Nandhikonda P, Begaye MP, Cao Z, Heagy MD (2009) Chem Commun 45:4941-4943

33. Lippert VEZ (1957) Elektrochem 61:962

34. Mataga N, Kaifu Y, Koizumi M (1956) Bull Chem Soc Jpn 29:465

35. Mataga N (1963) Bull Chem Soc Jpn 36:654 